Article

\title{
Simple Fast Quantification of Cholecalciferol, 25-Hydroxyvitamin D and 1,25-Dihydroxyvitamin D in Adipose Tissue Using LC-HRMS/MS
}

\author{
Laurianne Bonnet ${ }^{1, \dagger}$, Marielle Margier ${ }^{1, \dagger}$, Ljubica Svilar ${ }^{2, \dagger}$, Charlene Couturier ${ }^{1}$, \\ Emmanuelle Reboul ${ }^{1}{ }^{\circledR}$, Jean-Charles Martin ${ }^{1,2}$, Jean-François Landrier ${ }^{1,2}$ and \\ Catherine Defoort ${ }^{1,2, *}$ \\ 1 C2VN (Centre de Recherche CardioVasculaire et Nutrition), INRA, INSERM, Université d'Aix-Marseille, \\ Faculté de Médecine, 27 Bd Jean Moulin, 13385 Marseille CEDEX 05, France \\ 2 CriBioM, Criblage Biologique Marseille, Faculté de médecine de la Timone, 13005 Marseille, France \\ * Correspondence: catherine.defoort@univ-amu.fr; Tel.: +33-4-91-32-42-82; Fax: +33-4-91-78-21-01 \\ + These three authors contributed equally to this work.
}

Received: 17 June 2019; Accepted: 17 August 2019; Published: 22 August 2019

\begin{abstract}
Vitamin D metabolism is actively modulated in adipose tissue during obesity. To better investigate this process, we develop a specific LC-HRMS/MS method that can simultaneously quantify three vitamin D metabolites, i.e., cholecalciferol, 25-hydroxyvitamin $\mathrm{D}_{3}\left(25(\mathrm{OH}) \mathrm{D}_{3}\right)$, and 1,25-dihydroxyvitamin $\mathrm{D}_{3}\left(1,25(\mathrm{OH})_{2} \mathrm{D}_{3}\right)$ in a complex matrix, such as mouse adipose tissue and plasma. The method uses pretreatment with liquid-liquid or solid-phase extraction followed by derivatization using Amplifex ${ }^{\circledR}$ reagents to improve metabolite stability and ionization efficiency. Here, the method is optimized by co-eluting stable isotope-labelled internal standards to calibrate each analogue and to spike biological samples. Intra-day and inter-day relative standard deviations were $0.8-6.0 \%$ and $2.0-14.4 \%$, respectively for the three derivatized metabolites. The limits of quantification (LoQ) achieved with Amplifex ${ }^{\circledR}$ derivatization were $0.02 \mathrm{ng} / \mathrm{mL}, 0.19 \mathrm{ng} / \mathrm{mL}$, and $0.78 \mathrm{ng} / \mathrm{mL}$ for $1,25(\mathrm{OH})_{2} \mathrm{D}_{3}, 25(\mathrm{OH}) \mathrm{D}_{3}$ and cholecalciferol, respectively. Now, for the first time, $1,25(\mathrm{OH})_{2} \mathrm{D}_{3}$ can be co-quantified with cholecalciferol and $25(\mathrm{OH}) \mathrm{D}_{3}$ in mouse adipose tissue. This validated method is successfully applied to study the impact of obesity on vitamin D status in mice.
\end{abstract}

Keywords: vitamin D metabolite quantification; LC-MS/MS; adipose tissue; obesity

\section{Introduction}

Vitamin D (VD), or cholecalciferol, is a prohormone involved in calcium and phosphate homeostasis. VD insufficiency, or deficiency, is directly linked to well-known bone diseases including rickets, osteoporosis, and osteomalacia [1], and may be involved in a number of other pathophysiological disorders, including cardiovascular disease or type 2 diabetes. After endogenous synthesis or intestinal absorption [2], cholecalciferol is metabolized in the liver by 25-hydroxylases that produce 25-hydroxyvitamin $\mathrm{D}$ [3]. The major form of VD found in plasma is $25(\mathrm{OH}) \mathrm{D}_{3}$, which is considered the best biomarker of VD status [4]. 25(OH)D can be hydroxylated in the kidney or in target tissues [5] by CYP27B1 into $1 \alpha, 25$-dihydroxyvitamin D, which is the active form of VD.

Several studies and a recent review [6,7] highlighted that adipose tissue is one of the main storage sites for cholecalciferol and $25(\mathrm{OH}) \mathrm{D} 3$, and the mechanism of cholecalciferol and $25(\mathrm{OH}) \mathrm{D}_{3}$ uptake by adipocytes was recently identified [8]. Obesity is commonly associated with vitamin D deficiency $[9,10]$, but there is no clear picture or even consensus on the mechanism(s) underpinning vitamin D status in obesity. One often-cited mechanism is deposition and sequestration of vitamin D metabolites in 
adipose tissue stores, but there is little experimental evidence to support this hypothesis. We recently demonstrated that cholecalciferol and $25(\mathrm{OH}) \mathrm{D} 3$ storage could result from an active mechanism involving modulated expression of several cytochromes [11].

One of the most informative ways to explore VD-related health and metabolism is to simultaneously measure VD metabolites in key organs. Consequently, the frequency of routine analytical measurement of VD status has increased greatly [12], necessitating the development of reliable and accurate analytical methods to measure concentration levels of VD metabolites not only in plasma but also in relevant body tissues [13]. Numerous liquid chromatography-tandem mass spectrometry (LC-MS/MS) methods have been described for measuring VD metabolites individually or in combination [14-21], but few papers reported the absolute quantification of cholecalciferol and 25(OH)D3 in adipose tissue by high-performance liquid chromatography tandem-mass spectrometry (HPLC-MS/MS) [22-24], and none of them include the detection of $1,25(\mathrm{OH}) 2 \mathrm{D} 3$ with satisfactory sensitivity $[25,26]$.

Here, to address this gap, we set out to develop and validate a liquid-chromatography high-resolution tandem mass spectrometry (LC-HRMS/MS) method for simultaneous and accurate determination of cholecalciferol, 25(OH)D3 and 1,25(OH)2D3 in mouse adipose tissue. This effort carried a number of challenges, chiefly (i) the low in-sample concentrations of these metabolites, especially 1,25(OH)2D3 which is biologically active at picomolar concentrations, and (ii) the small amounts of tissue samples available, especially samples from mouse studies. The need to increase ionization efficiency and sensitivity implied a sample pretreatment, so we opt to use Amplifex ${ }^{\circledR}$ as a derivatizing reagent applicable to diene analytes. We apply our validated method to quantify the three vitamin D metabolites in adipose tissue and plasma from C57BL/6J mice fed for 11 weeks on either a control diet (control, $10 \%$ energy from fat) or a high-fat diet (HF, $60 \%$ energy from fat) formulated to provide equivalent vitamin $\mathrm{D}$ intake in both groups.

\section{Material and Methods}

\subsection{Materials}

Cholecalciferol, 25(OH)D3, 1,25(OH)2D3, dibasic potassium phosphate $\left(\mathrm{K}_{2} \mathrm{HPO}_{4}\right)$, methyl tert-butyl ether (MTBE), and phosphate buffer saline (PBS) were purchased from Sigma-Aldrich. Amplifex ${ }^{\circledR}$ Diene reagent was purchased from Sciex (Chemistry and Consumables R\&D, Framingham, $\mathrm{MA})$. Isotopically-labelled d3-cholecalciferol, d3-25(OH)D3, and d3-1,25(OH)2D3 were purchased from Cambridge Isotope Laboratories (MA). These three labelled molecules were deuterated in position $6,19,19$ and have been used as internal standards for the precision of the method. All vitamin D metabolites were stored at $-80^{\circ} \mathrm{C}$ in the dark. LC-MS-grade acetonitrile $(\mathrm{AcN})$ and formic acid and HPLC-grade methanol (MeOH) and ethyl acetate (EtOAc) were obtained from Carlo Erba Reagents (Peypin, France). The water used was generated through a Direct-Q Ultrapure Water System from Millipore (Bedford, MA) with a specific resistance of $18.2 \mathrm{M} \Omega \mathrm{cm}$. Oasis HLB cartridges used for solid-phase extraction (3 CC/60 mg) were supplied by Waters (Guyancourt, France). Mouse samples were taken on euthanized animals (C57Bl/6J male mice) according to the local animal ethics committee protocols (APAFIS\#2595-2016091911217758).

\subsection{Instrumentation}

Chromatographic separation was carried out on a Dionex UltiMate 3000 system (Thermo Fisher Scientific, Waltham, MA) configured with a rapid separation (RS) pump (LPG-3400 RS), an autosampler (WPS-3000 TRS) and a column compartment (TCC-3000 RS), all operated by Chromeleon 6.8 software. Samples were injected on a Hypersil GOLD C18 column $(2.1 \times 100 \mathrm{~mm}$; Thermo Scientific, Les Ulis, France). Parallel reaction monitoring (PRM and accurate mass measurements were performed on a Q-Exactive Plus mass spectrometer (Thermo Fisher Scientific, Bremen, Germany) with a heated electrospray ionization (H-ESI II) probe. Thermo Xcalibur 3.0.63 software was used for both instrument 
setup and LC-MS system control during data acquisition, and for data treatment. Q Exactive Plus Tune 2.5 software was used for direct control of the mass spectrometer.

\subsection{Chromatography Conditions}

The autosampler tray was kept at $4{ }^{\circ} \mathrm{C}$ during the experiment, and column oven temperature was regulated at $40{ }^{\circ} \mathrm{C} .5 \mu \mathrm{L}$ of sample was injected onto the column. Mobile phase A consisted of $0.1 \%$ formic acid in water, and mobile phase B was $0.1 \%$ formic acid in AcN. Solvent flow rate was set to $400 \mu \mathrm{L} / \mathrm{min}$. Starting mobile phase consisted of $30 \%$ of solvent B held for $4 \mathrm{~min}$. A linear gradient was applied with B \% increased to $65 \%$ for $6 \mathrm{~min}$, held isocratic for $2 \mathrm{~min}$, then increased to $100 \%$ of B for $4 \mathrm{~min}$. Start conditions were reinstated in $2 \mathrm{~min}$, making the total run time $18 \mathrm{~min}$.

\subsection{Mass Spectrometry Conditions}

LC-HRMS/MS analyses were performed with external calibration in positive mode providing a mass precision lower than $5 \mathrm{ppm}$. The H-ESI probe was kept at $310^{\circ} \mathrm{C}$. Transfer capillary temperature was kept at $320^{\circ} \mathrm{C}$. Spray voltage was set at $3500 \mathrm{~V}$ and the S-lens RF level was set at $55 \mathrm{~V}$. Sheath and auxiliary gas were held at 30 and 8 (arbitrary units).

PRM was set up in MS/MS acquisition mode, and full higher-energy collision dissociation (HCD) spectra were acquired. For each compound, the most abundant ion was selected as precursor ion and isolated in a 2 Uma window in a specified time segment and fragmented under previously optimized collision energies (Table 1). Resolving power was set to 35,000 full width at half maximum (FWMH) at $m / z 200$ and the Auto Gain Control (AGC) was set to $2 \times 10^{5}$. Injection time was set to a maximum of $100 \mathrm{~ms}$ in order to optimize the analytical cycle time.

Table 1. Precursor and product ions $m / z$ values, retention times, and normalized collision energies for Amplifex-derivatized cholecalciferol, 25(OH)D3, 1,25(OH)2D3, and the corresponding isotopically-labeled molecule for absolute quantification.

\begin{tabular}{cccccc}
\hline Compound Name & $\begin{array}{c}\text { Precursor } \\
\text { Ion }\end{array}$ & $\begin{array}{c}\text { Precursor } \\
\boldsymbol{m} / \boldsymbol{z}\end{array}$ & $\begin{array}{c}\text { Product } \\
\boldsymbol{m} / \boldsymbol{z}\end{array}$ & $\begin{array}{c}\text { Retention } \\
\text { Time (min) }\end{array}$ & $\begin{array}{c}\text { Collision } \\
\text { Energy (\%) }\end{array}$ \\
\hline Cholecalciferol-Amplifex & {$[\mathrm{M}]+$} & 716.50 & 657.43 & $13.2+13.5$ & 21 \\
25(OH)D3-Amplifex & {$[\mathrm{M}]+$} & 732.51 & 673.43 & 9.7 & 21 \\
1,25(OH)2D3-Amplifex & {$[\mathrm{M}]+$} & 748.51 & 689.42 & 8.6 & 21 \\
d3-cholecalciferol-Amplifex & {$[\mathrm{M}]+$} & 719.50 & 660.45 & $13.2+13.5$ & 21 \\
d3-25(OH)D3-Amplifex & {$[\mathrm{M}]+$} & 735.50 & 676.45 & 9.7 & 21 \\
d3-1,25(OH)2D3-Amplifex & {$[\mathrm{M}]+$} & 751.50 & 692.44 & 8.6 & 21 \\
\hline
\end{tabular}

\subsection{Preparation of stock and working solutions of analytical and deuterated standards (IS)}

A working solution of deuterated analytes was prepared at $0.02 \mathrm{ng} / \mathrm{mL}$ of each internal standard (IS) (d3-cholecalciferol, d3-25(OH)D3 and d3-1,25(OH)2D3) in ethanol. Stock solutions of cholecalciferol, 25(OH)D3 and 1,25(OH)2D3 standards were prepared at 100, 50 and $10 \mathrm{ng} / \mathrm{mL}$, respectively in ethanol and stored at $-80^{\circ} \mathrm{C}$ in the dark. Calibration curves were prepared by serial dilution of the three analyte stock solutions to obtain calibration standards from 0 to $50 \mathrm{ng} / \mathrm{mL}$. After $1.5 \mu \mathrm{L}$ of the working solution of deuterated analytes was added to each dilution, derivatization was performed using Amplifex ${ }^{\circledR}$. A batch of Quality Control (QC) samples was produced for method validation.

\subsection{Animals, Diets, and Experiments}

Six-week-old male C57BL/6J mice were obtained from Janvier Labs (Le Genest-Saint-Isle, France) and fed ad libitum with standard chow (maintenance diet A04, Safe Diets, Augy, France) during a one week acclimatization period with ad libitum access to drinking water, housed at $22{ }^{\circ} \mathrm{C}$ under a $12 \mathrm{~h} / 12 \mathrm{~h}$ light/dark cycle at $20 \%$ relative humidity. The mice were then divided into two groups: a control-diet group (control: 10\% energy from lipids, $n=10$ ) and a high-fat-diet group (HF: $60 \%$ energy 
from lipids, $n=10$ ) (TestDiet, London, UK). Blood and adipose tissue were collected after 11 weeks on either the control or high-fat diet.

Composition of the experimental diet is detailed in Supplementary Table S1. Morphology (body weight and adiposity index) and food intake (energy intake and vitamin D intake) parameters were also controlled and measured (Supplementary Tables S2 and S3, respectively). Further details can be found in Bonnet et al. (2019) [11].

\subsection{Plasma Sample Preparation}

At the end of the 11-week diet period, the mice were fasted overnight and blood was collected by cardiac puncture under anesthesia. Plasma was obtained after centrifugation at $3000 \times g$ for $15 \mathrm{~min}$ at $4{ }^{\circ} \mathrm{C}$, and stored at $-80^{\circ} \mathrm{C}$. The plasma preparation procedure was inspired by Wang et al. [27]. As vitamin $\mathrm{D}$ and its metabolites are light-sensitive, the extraction procedure was conducted under low light. After thawing on ice, mouse plasma was centrifuged at $13,600 \times g$ for $15 \mathrm{~min}$ at $4{ }^{\circ} \mathrm{C}$, then $100 \mu \mathrm{L}$ of each sample was transferred to a glass tube with $10 \mu \mathrm{L}$ of deuterated working solution. Proteins were precipitated by adding $500 \mu \mathrm{L}$ of $\mathrm{AcN}$, vortex-mixed, and centrifuged at $3000 \times g$ for $10 \mathrm{~min}$ at $4{ }^{\circ} \mathrm{C}$. The supernatant was transferred to another glass tube, then the volume was reduced to one half under a nitrogen stream, and $500 \mu \mathrm{L}$ of EtOAc was added to the solution for liquid-liquid extraction. After shaking vigorously for $10 \mathrm{~min}$, samples were centrifuged at $590 \times \mathrm{g}$ for $20 \mathrm{~min}$ at $4{ }^{\circ} \mathrm{C}$, and the upper organic layer was transferred to a glass tube and reduced under nitrogen stream. The plasma samples were then derivatized with Amplifex ${ }^{\circledR}$ Diene reagent.

For validation, a set of plasmas were pooled together and treated as described above.

\subsection{Adipose Tissue Preparation}

The animals were sacrificed by cervical dislocation under anesthesia, and the epididymal white adipose tissue (eWAT) was collected, weighed, snap-frozen in liquid nitrogen, and stored at $-80^{\circ} \mathrm{C}$. The adipose tissue preparation procedure was inspired by Lipkie et al. [24]. After thawing on ice, $50 \mathrm{mg}$ of tissue was ground with $1 \mathrm{~mL}$ of PBS at $30 \mathrm{mvt} / \mathrm{s}$ or $15 \mathrm{~min}$ (Retsch, Eragny-sur-Oise, France). Tissue homogenate was transferred into a glass tube and spiked with $25 \mu \mathrm{L}$ of deuterated stock solution. AcN $(1 \mathrm{~mL})$ was added, and the mixture was vortexed for $5 \mathrm{~min}$ then centrifuged at $6000 \times g$ for $5 \mathrm{~min}$ at $4{ }^{\circ} \mathrm{C}$. After addition of $1 \mathrm{~mL}$ of MTBE, the mixture was vortexed for $5 \mathrm{~min}$, then centrifuged at $6000 \times$ $g$ for $5 \mathrm{~min}$ at $4{ }^{\circ} \mathrm{C}$, and the upper organic layer was collected in another tube. The same extraction was repeated twice more with additions of $300 \mu \mathrm{L}$ of PBS, $1 \mathrm{~mL}$ of AcN (vortex + centrifugation) and $1 \mathrm{~mL}$ of MTBE (vortex + centrifugation). The supernatants were pooled then dried under nitrogen. Oasis HLB cartridges were prepared with $3 \mathrm{~mL}$ each of EtOAc, $\mathrm{MeOH}$, and $\mathrm{H}_{2} \mathrm{O}$. The samples were reconstituted with $1 \mathrm{~mL}$ of $\mathrm{MeOH}$ and $1 \mathrm{~mL}$ of $\mathrm{K}_{2} \mathrm{HPO}_{4}(0.4 \mathrm{M})$ and loaded on the cartridge. The cartridge was washed with $3 \mathrm{~mL}$ of $\mathrm{H}_{2} \mathrm{O}$ and $2 \mathrm{~mL}$ of $70 \% \mathrm{MeOH}$ before being dried for 2 min under vacuum. Tips were washed with $\mathrm{AcN}$ and analytes were eluted with $1.5 \mathrm{~mL}$ of $\mathrm{AcN}$ and dried under nitrogen. Samples were then derivatized with Amplifex ${ }^{\circledR}$ reagent.

For validation, a set of adipose tissues were pooled together and treated as described above.

\subsection{Amplifex Derivatization}

A one-step derivatization using Amplifex ${ }^{\circledR}$ Diene as reagent was employed to improve the ionization efficiency of the metabolites [17]. The dried sample was added with $30 \mu \mathrm{L}$ of Amplifex ${ }^{\circledR}$ solution, vortexed for $15 \mathrm{~s}$, then incubated for $30 \mathrm{~min}$ at room temperature. Next, $30 \mu \mathrm{L}$ of deionized water was added to the sample, vortexed for $15 \mathrm{~s}$, and transferred into vials for LC injection.

\subsection{Method Validation}

Our method was validated according to FDA criteria adapted from Shah et al. [28], and we evaluated specificity, selectivity, linearity, sensitivity, accuracy, precision, stability, and dilution tests. 


\subsubsection{Linearity and Limits of Quantification (LoQ)}

In order to assess the linearity of the quantification methods, we analyzed increasing amounts of analytical-standard solution spiked with the deuterated pool of the three corresponding analytes. For each derivatization reagent and each analyte, i.e., cholecalciferol, 25(OH)D3 and 1,25(OH)2D3, calibration curves were plotted with peak area ratio of vitamin D metabolite to the respective internal standard versus a range of analyte concentrations. For cholecalciferol, these two peaks represent diastereomers 13.2- and 13.5-min retention times. As the tandem-mass spectra showed the same pattern (same product ion and relative intensities), we summed their peak areas for the quantification.

Five concentrations of standards were chosen to cover the expected concentration range in the study. The series of concentrations were $0.20-50 \mathrm{ng} / \mathrm{mL}$ for cholecalciferol, $0.10-12.5 \mathrm{ng} / \mathrm{mL}$ for $25(\mathrm{OH}) \mathrm{D} 3$, and $0.020-2.5 \mathrm{ng} / \mathrm{mL}$ for $1,25(\mathrm{OH}) 2 \mathrm{D} 3$. We processed five replicates for each concentration level.

The LoQ was set as the concentration at which precision was less than $20 \%$ of the relative standard deviation, with an accuracy of between $80 \%$ and $120 \%$ of the theoretical value [29].

\subsubsection{Accuracy and Precision}

Replicated samples at three concentration levels were analyzed in separate runs to determine intra-day and inter-day precision and accuracy.

Intra-day accuracy and precision were calculated by processing five replicates at three concentration levels. Inter-day accuracy and precision were determined by analyzing five replicate samples in 3 batches $(n=15)$ at three concentration levels.

Precision of the assay was estimated by the coefficient of variation for each concentration level. Accuracy was represented as the relative error to the nominal concentrations (RE \%), calculated as ratio of the deviation to the theoretical value $\times 100$.

\section{Statistical Analysis}

The data are reported as means \pm SEM. Significant differences were determined using a Student's $t$-test, with the threshold for statistical significance set at $p<0.05$.

\section{Results and Discussion}

\subsection{Method Validation}

\subsubsection{LC-HRMS/MS}

The optimal separation was achieved with linear gradient conditions using $\mathrm{AcN} / \mathrm{H}_{2} \mathrm{O}$ (with $0.1 \%$ FA) as mobile phase on a C18 column, as shown in Figure 1.

The three vitamin D-Amplifex ${ }^{\circledR}$ derivates were chromatographically resolved from each other (Peak Resolution: Rs >1.5). Tandem mass spectrometry analysis combined with satisfactory chromatographic separation ensured high specificity and selectivity of the method (Supplementary Figures S1 and S2).

The recently-developed reagent Amplifex is a 4-phenyl-1,2,4-triazoline-3,5-dione (PTAD) base with a naturally ionized quaternary ammonium group. It further enhances ionization efficiency compared to PTAD and thus achieves lower detection limits. This may explain the higher sensitivity of the Multiple Reaction Monitoring (MRM) methods for quantification of Amplifex-derivatized VD compared to PTAD-derivatized VD. As expected, the Amplifex reagent gave a lower LoQ than PTAD and thus emerges as the preferred method for derivatization. The scope of LC-MS/MS methods published to date has been limited to the quantification of one or two vitamin D metabolites in a single run. There is now a consensus that derivatization techniques can maximize both selectivity and sensitivity, and here we show the value of this derivatization method for enabling simultaneous and accurate LC-HRMS/MS quantification of cholecalciferol, 25(OH)D3, and 1,25(OH)2D3 in plasma and adipose tissue $[16,17,19,20]$. 


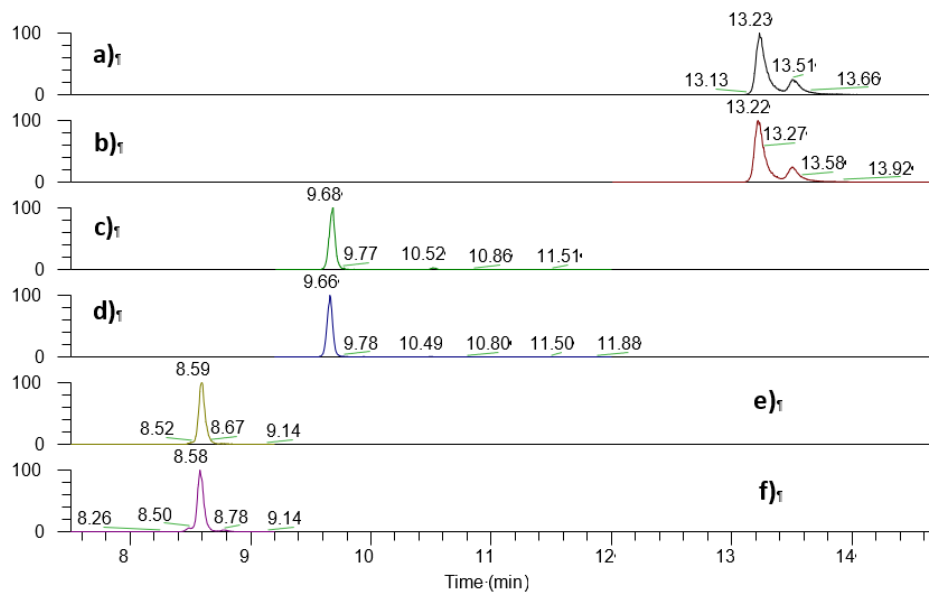

Figure 1. Extracted Ion Chromatography of standards mixed solution derivatized with Amplifex reagent. (a) $m / z 657.43$ extracted from the MS/MS spectrum of the $m / z 716.50$ ion of cholecalciferol, (b) $\mathrm{m} / \mathrm{z} 660.45$ extracted from the MS/MS spectrum of the $\mathrm{m} / \mathrm{z} 719.50$ ion of d3-cholecalciferol, (c) $\mathrm{m} / \mathrm{z}$ 673.43 extracted from MS/MS spectrum of the $m / z 732.51$ ion of $25(\mathrm{OH}) \mathrm{D} 3$, (d) $\mathrm{m} / \mathrm{z} 676.45$ extracted from MS/MS spectrum of the $m / z 735.50$ ion of $\mathrm{d} 3-25(\mathrm{OH}) \mathrm{D} 3$, (e) $\mathrm{m} / \mathrm{z} 689.42$ extracted from MS/MS spectrum of the $\mathrm{m} / \mathrm{z} 748.51$ ion of 1,25(OH)2D3 and (f) $\mathrm{m} / \mathrm{z} 692.44$ extracted from MS/MS spectrum of the $\mathrm{m} / \mathrm{z}$ 751.50 ion of $\mathrm{d} 3-1,25(\mathrm{OH}) 2 \mathrm{D} 3$.

\subsubsection{Linearity, LoQ and Calibration Curves}

The data were fitted using linear regression. Table 2 reports linear range and LoQ for the derivatized metabolites. Regression analysis showed good linearity with correlation coefficients $\left(r^{2}\right)$ $>0.993$ for the three analytes.

Table 2. Linear range, limits of quantification (LoQ) and RE \% for the 3 metabolites derivatized with Amplifex ${ }^{\circledR}$. RE was determined for LoQ concentration (RE \%: Relative error to the nominal concentrations).

\begin{tabular}{cccc}
\hline Analytes & Linear Range $\mathbf{n g} / \mathbf{m L}$ & LoQ $\mathbf{~ g} / \mathbf{m L}$ & RE \% \\
\hline Cholecalciferol & $0.20-50$ & 0.78 & -5.3 \\
25(OH)D3 & $0.10-12.5$ & 0.19 & 4.0 \\
1,25(OH)2D3 & $0.02-2.5$ & 0.02 & 17.3 \\
\hline
\end{tabular}

The range of linearity range was considered as the working range.

\subsubsection{Precision and Accuracy}

Table 3 summarizes the precision (\%CV) and accuracy (\%RE) of the method according to derivatization procedure for simultaneous quantification of all three vitamin D metabolites. Using Amplifex ${ }^{\circledR}$ derivatization, the intra-assay variation ranged between $0.8 \%$ and $6 \%$ depending on the vitamin $\mathrm{D}$ metabolite and concentration considered, and the inter-assay variation was between $2 \%$ and $14.4 \%$. The RE of the three tested concentrations in three independent assays were within $\pm 3 \%, \pm 9 \%$ and $\pm 14 \%$ for cholecalciferol, $25(\mathrm{OH}) \mathrm{D} 3$ and $1,25(\mathrm{OH}) 2 \mathrm{D} 3$, respectively. These results indicate good reproducibility and accuracy of the method. The $\% \mathrm{CV}$ and $\% \mathrm{RE}$ are all $<15 \%$.

\subsubsection{Dilution Test and Stability}

The dilution test with high-concentration overloaded plasma samples showed between $83 \%$ and $110 \%$ recovery (data not shown).

We tested the stability of derivatized vitamin D metabolites. The Amplifex-derivatized metabolites showed a signal decrease after $24 \mathrm{~h}$ in the autosampler $\left(5^{\circ} \mathrm{C}\right)$ from $-15.3 \pm 0.5 \%,-19.7 \pm 2.0 \%,-42.6 \pm$ $2.0 \%$ for cholecalciferol, $25(\mathrm{OH}) \mathrm{D} 3$ and $1,25(\mathrm{OH}) 2 \mathrm{D} 3$, respectively (Data not shown). These stability results fit with what we expected based on Amplifex ${ }^{\circledR}$ Diene reagent guidance for users. 
Table 3. Precision and accuracy of cholecalciferol, 25(OH)D3 and 1,25(OH)2D3 measurements.

\begin{tabular}{|c|c|c|c|c|c|c|}
\hline \multirow{2}{*}{$\begin{array}{l}\text { Compound and } \\
\text { Concentration }\end{array}$} & \multicolumn{3}{|c|}{ Intra-Assay $(n=5)^{a}$} & \multicolumn{3}{|c|}{ Inter-assay $(n=3)^{b}$} \\
\hline & Measured $^{c}$ & $\% \mathrm{RE}^{\mathrm{d}}$ & $\% \mathrm{CV}^{\mathrm{e}}$ & Measured $^{c}$ & $\%$ RE $^{d}$ & $\% \mathrm{CV}^{\mathrm{e}}$ \\
\hline \multicolumn{7}{|c|}{ Cholecalciferol } \\
\hline $1.56 \mathrm{ng} / \mathrm{mL}$ & $1.53 \pm 0.01$ & -1.7 & 1.0 & $1.57 \pm 0.09$ & 0.9 & 12.7 \\
\hline $3.13 \mathrm{ng} / \mathrm{mL}$ & $3.31 \pm 0.06$ & 6.2 & 2.6 & $3.09 \pm 0.28$ & -1.2 & 9.0 \\
\hline $12.5 \mathrm{ng} / \mathrm{mL}$ & $12.9 \pm 0.13$ & 3.2 & 1.3 & $12.1 \pm 0.25$ & -2.9 & 2.0 \\
\hline \multicolumn{7}{|c|}{$25(\mathrm{OH}) \mathrm{D} 3$} \\
\hline $0.78 \mathrm{ng} / \mathrm{mL}$ & $0.81 \pm 0.03$ & 4.1 & 6.0 & $0.74 \pm 0.09$ & 9.3 & 11.1 \\
\hline $1.56 \mathrm{ng} / \mathrm{mL}$ & $1.70 \pm 0.04$ & 9.0 & 3.7 & $1.49 \pm 0.10$ & -4.2 & 7.1 \\
\hline $6.25 \mathrm{ng} / \mathrm{mL}$ & $6.36 \pm 0.12$ & 1.8 & 2.7 & $5.83 \pm 0.18$ & -6.8 & 3.1 \\
\hline \multicolumn{7}{|c|}{$1,25(\mathrm{OH}) 2 \mathrm{D} 3$} \\
\hline $0.16 \mathrm{ng} / \mathrm{mL}$ & $0.15 \pm 0.001$ & -6.3 & 1.5 & $0.18 \pm 0.01$ & 14.4 & 13.0 \\
\hline $0.31 \mathrm{ng} / \mathrm{mL}$ & $0.32 \pm 0.002$ & 5.1 & 0.8 & $0.31 \pm 0.04$ & 0.1 & 14.4 \\
\hline $1.25 \mathrm{ng} / \mathrm{mL}$ & $1.32 \pm 0.02$ & 5.8 & 1.9 & $1.23 \pm 0.03$ & -1.6 & 2.8 \\
\hline
\end{tabular}

a intra-assay precision was calculated for 5 replicates measured in a single run; ${ }^{\mathrm{b}}$ inter-assay precision was calculated from 3 independent assays. ${ }^{c}$ Means \pm SD of measured concentrations. ${ }^{d}$ Percent of relative error $(\% R E)$ is defined as the ratio of the deviation to the theoretical value $\times 100$. ${ }^{\mathrm{e}}$ Coefficient of variance is defined as the ratio of the standard deviation to the mean value $\times 100$.

\subsection{Impact of High-Fat Diet on Vitamin D Metabolites in Plasma and in Adipose Tissue}

After validation of the method, we quantified the three vitamin D metabolites in plasma and adipose tissue from the mouse study (Supplementary Figure S3).

In plasma, after 11 weeks of HF diet, compared to control diet, cholecalciferol concentration significantly decreased whereas $25(\mathrm{OH}) \mathrm{D} 3$ concentration increased and 1,25(OH)2D3 concentration remained unchanged. In eWAT, HF diet decreased cholecalciferol and 1,25(OH)2D3 concentrations but had no effect on 25(OH)D3 concentrations (Table 4). However, $25(\mathrm{OH}) \mathrm{D} 3$ was stronger in quantity terms (3.2-fold increase). These results are in agreement with Carrelli et al. [30], supporting the hypothesis that the large amount of adipose tissue in obese individuals serves as a reservoir for vitamin D. Here, our findings push the hypothesis further, with the quantification of 1,25(OH)2D3 concentration pointing to an active role of adipose tissue in the modulation of vitamin D metabolism during obesity. Note too that $1,25(\mathrm{OH}) 2 \mathrm{D} 3$ was also higher in quantity in obese mice compared to control mice (Table 4).

Table 4. Concentrations and quantities of the three Amplifex-derivatized vitamin $\mathrm{D}_{3}$ metabolites in mouse plasma and adipose tissue after 11 weeks of diet. The quantities in adipose tissue were calculated as concentration $x$ mass of epididymal white adipose tissue (eWAT).

\begin{tabular}{|c|c|c|c|}
\hline & Cholecalciferol & 25(OH)D3 & 1,25(OH)2D3 \\
\hline \multicolumn{4}{|c|}{ Plasma concentration } \\
\hline Control & $2.6 \pm 0.1 \mathrm{ng} / \mathrm{mL}$ & $38.4 \pm 0.9 \mathrm{ng} / \mathrm{mL}$ & $0.24 \pm 0.02 \mathrm{ng} / \mathrm{mL}$ \\
\hline $\mathrm{HF}$ & $1.3 \pm 0.1 \mathrm{ng} / \mathrm{mL}^{*}$ & $42.7 \pm 1.4 \mathrm{ng} / \mathrm{mL}^{*}$ & $0.24 \pm 0.01 \mathrm{ng} / \mathrm{mL}$ \\
\hline \multicolumn{4}{|c|}{ Adipose tissue concentration } \\
\hline Control & $332 \pm 25 \mathrm{ng} / \mathrm{g}$ & $51 \pm 4 \mathrm{ng} / \mathrm{g}$ & $45 \pm 6 \mathrm{ng} / \mathrm{g}$ \\
\hline HF & $236 \pm 31 \mathrm{ng} / \mathrm{g}$ * & $62 \pm 8 \mathrm{ng} / \mathrm{g}$ & $26 \pm 6 \mathrm{ng} / \mathrm{g}^{*}$ \\
\hline \multicolumn{4}{|c|}{ Adipose tissue quantity } \\
\hline Control & $284 \pm 29 \mathrm{ng}$ & $44 \pm 5 \mathrm{ng}$ & $40 \pm 6 \mathrm{ng}$ \\
\hline $\mathrm{HF}$ & $548 \pm 61 \mathrm{ng} *$ & $140 \pm 12$ ng * & $61 \pm 14 \mathrm{ng}^{*}$ \\
\hline
\end{tabular}

Control diet: $n=10$, HF diet, high-fat diet: $n=10$. Values are presented as means \pm SEM. Significant differences were determined by a Student's $t$-test * $p<0.05$. 


\section{Conclusions}

The use of a recently developed derivatization reagent Amplife ${ }^{\circledR}$ affords dramatically enhanced ionization efficiency, thus achieving lower detection limits and making it possible to detect picomolar-concentration metabolites. We have developed and validated a powerful LC-HRMS/MS technique to simultaneously quantify key analytes of interest in complex samples other than plasma. Here we used the method to quantify 1,25(OH)2D3 along with cholecalciferol and 25(OH)D3 in adipose tissue to extend research into the hypothesis of vitamin D metabolite storage and production, especially in obesity settings [11].

Supplementary Materials: The following are available online at http://www.mdpi.com/2072-6643/11/9/1977/s1, Figure S1: MS/MS spectrum of 1,25(OH)2D3, 25(OH)D3 and cholecalciferol derivatized with Amplifex reagent and their respective deuterated forms, Figure S2: Derivatization reaction, Figure S3: Extrated Ion Chromatography of plasma (A) and adipose tissue (B) sample derivatized with Amplifex reagent (a) $m / z 657.43$ extracted from the MS/MS spectrum of $m / z 716.50$ ion of cholecalciferol-Amplifex, (b) $\mathrm{m} / \mathrm{z} 660.45$ extracted from the MS/MS spectrum of $m / z 719.50$ ion of d3-cholecalciferol-Amplifex, (c) $m / z 673.43$ extracted from MS/MS spectrum of $m / z 732.51$ ion of 25(OH)D3-Amplifex, (d) $m / z$ 676.45 extracted from MS/MS spectrum of $m / z 735.50$ ion of d3-25(OH)D3-Amplifex, (e) $\mathrm{m} / z 689.43$ extracted from MS/MS spectrum of $\mathrm{m} / \mathrm{z} 748.51$ ion of 1,25(OH)2D3-Amplifex and (f) $\mathrm{m} / z$ 692.44 extracted from MS/MS spectrum of $m / z 751.50$ ion of d3-1,25(OH)2D3-Amplifex, Table S1: Experimental diet compositions, Table S2: Mice morphologic parameters, Table S3: Food intake parameters.

Author Contributions: C.D., L.S., J.-F.L. conceived and designed the experiments; L.B. and M.M. performed the experiments; L.B., M.M., L.S. and C.D. analyzed the data; C.C., J.-C.M. contributed to reagents/materials/analysis tools; C.D. and L.B. wrote the paper with the contribution of E.R. and J.-F.L.

Funding: This research received no external funding.

Conflicts of Interest: The authors declare no conflicts of interest.

\section{References}

1. Plum, L.A.; DeLuca, H.F.; Vitamin, D. Disease and therapeutic opportunities. Nat. Rev. Drug Discov. 2010, 9, 941-955. [CrossRef] [PubMed]

2. Reboul, E.; Goncalves, A.; Comera, C.; Bott, R.; Nowicki, M.; Landrier, J.F.; Jourdheuil-Rahmani, D.; Dufour, C.; Collet, X.; Borel, P.; et al. Intestinal absorption is not a simple passive diffusion: evidences for involvement of cholesterol transporters. Mol. Nutr. Food Res. 2011, 55, 691-702. [CrossRef] [PubMed]

3. Schuster, I. Cytochromes P450 are essential players in the vitamin D signaling system. Biochim. Biophys. Acta 2011, 1814, 186-199. [CrossRef] [PubMed]

4. Holick, M.F.; Vitamin, D. Deficiency. New Engl. J. Med. 2007, 357, 266-281. [CrossRef] [PubMed]

5. White, J.H. Regulation of intracrine production of 1,25-dihydroxyvitamin D and its role in innate immune defense against infection. Arch. Biochem. Biophys. 2012, 523, 58-63. [CrossRef] [PubMed]

6. Landrier, J.F.; Karkeni, E.; Marcotorchino, J.; Bonnet, L.; Tourniaire, F. Vitamin D modulates adipose tissue biology: possible consequences for obesity? Proc. Nutr. Soc. 2016, 75, 38-46. [CrossRef] [PubMed]

7. Landrier, J.F.; Marcotorchino, J.; Tourniaire, F. Lipophilic micronutrients and adipose tissue biology. Nutrients 2012, 4, 1622-1649. [CrossRef] [PubMed]

8. Bonnet, L.; Karkeni, E.; Couturier, C.; Astier, J.; Dalifard, J.; Defoort, C.; Svilar, L.; Martin, J.C.; Tourniaire, F.; Landrier, J.F. Gene expression pattern in response to cholecalciferol supplementation highlights cubilin as a major protein of 25(OH)D uptake in adipocytes and male mice white adipose tissue. Endocrinology 2018, 159, 957-966. [CrossRef]

9. Pereira-Santos, M.; Costa, P.R.; Assis, A.M.; Santos, C.A.; Santos, D.B. Obesity and vitamin D deficiency: A systematic review and meta-analysis. Obes. Rev. 2015, 16, 341-349. [CrossRef]

10. Vimaleswaran, K.S.; Berry, D.J.; Lu, C.; Tikkanen, E.; Pilz, S.; Hiraki, L.T.; Cooper, J.D.; Dastani, Z.; Li, R.; Houston, D.K.; et al. Causal relationship between obesity and vitamin D status: bi-directional Mendelian randomization analysis of multiple cohorts. PLoS Med. 2013, 10, e1001383. [CrossRef]

11. Bonnet, L.H.A.; Karkeni, E.; Couturier, C.; Astier, J.; Defoort, C.; Svilar, L.; Martin, J.C.; Tourniaire, F.; Landrier, J.F. Diet induced obesity modifies vitamin D metabolism and adipose tissue storage in mice. J. Steroid. Biochem. Mol. Biol. 2019, 185, 39-46. [CrossRef] [PubMed] 
12. El-Khoury, J.M.; Reineks, E.Z.; Wang, S. Progress of liquid chromatography-mass spectrometry in measurement of vitamin D metabolites and analogues. Clin. Biochem. 2011, 44, 66-76. [CrossRef] [PubMed]

13. Grebe, S.K.; Singh, R.J. LC-MS/MS in the clinical laboratory-Where to from here? Clin. Biochem. Rev. 2011, 32, 5-31. [PubMed]

14. Mena-Bravo, A.; Ferreiro-Vera, C.; Priego-Capote, F.; Maestro, M.A.; Mourino, A.; Quesada-Gomez, J.M.; Luque de Castro, M.D. Quantitative analytical method to evaluate the metabolism of vitamin D. Clin. Chim. Acta 2015, 442, 6-12. [CrossRef] [PubMed]

15. Shah, I.; Petroczi, A.; Naughton, D.P. Method for simultaneous analysis of eight analogues of vitamin D using liquid chromatography tandem mass spectrometry. Chem. Cent. J. 2012, 6, 112. [CrossRef] [PubMed]

16. Fang, H.; Yu, S.; Cheng, Q.; Cheng, X.; Han, J.; Qin, X.; Xia, L.; Jiang, X.; Qiu, L. Determination of 1,25-dihydroxyvitamin D2 and 1,25-dihydroxyvitamin D3 in human serum using liquid chromatography with tandem mass spectrometry. J. Chromatogr. B Anal. Technol. Biomed. Life Sci. 2016, 1027, 1-26. [CrossRef] [PubMed]

17. Hedman, C.J.; Wiebe, D.A.; Dey, S.; Plath, J.; Kemnitz, J.W.; Ziegler, T.E. Development of a sensitive LC/MS/MS method for vitamin D metabolites: 1,25 dihydroxyvitamin D2\&3 measurement using a novel derivatization agent. J. Chromatogr. B Anal. Technol. Biomed. Life Sci. 2014, 62-67. [CrossRef]

18. Abu Kassim, N.S.; Shaw, P.N.; Hewavitharana, A.K. Simultaneous determination of 12 vitamin D compounds in human serum using online sample preparation and liquid chromatography-tandem mass spectrometry. J. Chromatogr. A 2018, 1533, 57-65. [CrossRef]

19. Jenkinson, C.; Taylor, A.E.; Hassan-Smith, Z.K.; Adams, J.S.; Stewart, P.M.; Hewison, M.; Keevil, B.G. High throughput LC-MS/MS method for the simultaneous analysis of multiple vitamin D analytes in serum. J. Chromatogr. B Anal. Technol. Biomed. Life Sci. 2016, 1014, 56-63. [CrossRef]

20. Wan, D.; Yang, J.; Barnych, B.; Hwang, S.H.; Lee, K.S.; Cui, Y.; Niu, J.; Watsky, M.A.; Hammock, B.D. A new sensitive LC/MS/MS analysis of vitamin D metabolites using a click derivatization reagent, 2-nitrosopyridine. J. Lipid Res. 2017, 58, 798-808. [CrossRef]

21. Fabregat-Cabello, N.; Farre-Segura, J.; Huyghebaert, L.; Peeters, S.; Le Goff, C.; Souberbielle, J.C.; Cavalier, E. A fast and simple method for simultaneous measurements of $25(\mathrm{OH}) \mathrm{D}, 24,25(\mathrm{OH}) 2 \mathrm{D}$ and the Vitamin D Metabolite Ratio (VMR) in serum samples by LC-MS/MS. Clin. Chim. Acta 2017, 473, 116-123. [CrossRef] [PubMed]

22. Xue, Y.; He, X.; Li, H.D.; Deng, Y.; Yan, M.; Cai, H.L.; Tang, M.M.; Dang, R.L.; Jiang, P. Simultaneous quantification of 25-hydroxyvitamin D3 and 24,25-dihydroxyvitamin D3 in rats shows strong correlations between serum and brain tissue levels. Int. J. Endocrinol. 2015, 296531. [CrossRef]

23. Piccolo, B.D.; Dolnikowski, G.; Seyoum, E.; Thomas, A.P.; Gertz, E.R.; Souza, E.C.; Woodhouse, L.R.; Newman, J.W.; Keim, N.L.; Adams, S.H.; et al. Association between subcutaneous white adipose tissue and serum 25-hydroxyvitamin D in overweight and obese adults. Nutrients 2013, 5, 3352-3366. [CrossRef] [PubMed]

24. Lipkie, T.E.; Janasch, A.; Cooper, B.R.; Hohman, E.E.; Weaver, C.M.; Ferruzzi, M.G. Quantification of vitamin D and 25-hydroxyvitamin D in soft tissues by liquid chromatography-tandem mass spectrometry. J. Chromatogr. B Anal. Technol. Biomed. Life Sci. 2013, 932, 6-11. [CrossRef] [PubMed]

25. Ahonen, L.; Maire, F.B.; Savolainen, M.; Kopra, J.; Vreeken, R.J.; Hankemeier, T.; Myohanen, T.; Kylli, P.; Kostiainen, R. Analysis of oxysterols and vitamin D metabolites in mouse brain and cell line samples by ultra-high-performance liquid chromatography-atmospheric pressure photoionization-mass spectrometry. J. Chromatogr. A 2014, 1364, 214-222. [CrossRef] [PubMed]

26. Burild, A.; Frandsen, H.L.; Poulsen, M.; Jakobsen, J. Quantification of physiological levels of vitamin D(3) and 25-hydroxyvitamin $\mathrm{D}(3)$ in porcine fat and liver in subgram sample sizes. J. Sep. Sci. 2014, 37, 2659-2663. [CrossRef] [PubMed]

27. Wang, Z.; Senn, T.; Kalhorn, T.; Zheng, X.E.; Zheng, S.; Davis, C.L.; Hebert, M.F.; Lin, Y.S.; Thummel, K.E. Simultaneous measurement of plasma vitamin $\mathrm{D}(3)$ metabolites, including 4beta,25-dihydroxyvitamin $\mathrm{D}(3)$, using liquid chromatography-tandem mass spectrometry. Anal. Biochem. 2011, 418, 126-133. [CrossRef] [PubMed]

28. Shah, V.P.; Midha, K.K.; Findlay, J.W.; Hill, H.M.; Hulse, J.D.; McGilveray, I.J.; McKay, G.; Miller, K.J.; Patnak, R.N.; Powell, M.L.; et al. Bioanalytical method validation-A revisit with a decade of progress. Pharm. Res. 2000, 17, 1551-1557. [CrossRef] 
29. Armbruster, D.A.; Pry, T. Limit of blank, limit of detection and limit of quantitation. Clin. Biochem. Rev. 2008, 29, S49-S52.

30. Carrelli, A.; Bucovsky, M.; Horst, R.; Cremers, S.; Zhang, C.; Bessler, M.; Schrope, B.; Evanko, J.; Blanco, J.; Silverberg, S.; et al. Vitamin D storage in adipose tissue of obese and normal weight women. J. Bone Miner. Res. 2017, 32, 237-242. [CrossRef] 